\title{
Zinervaring in gesprek
}

\author{
Wim Smeets*
}

\begin{abstract}
Summary
In interfaith spiritual care, the emphasis is too much on the ideological contents (their generic correspondences or their special individuality), whether or not linked to an official mandate of the spiritual counselor. Worldview contents can indeed have a function in guiding clients, by offering a perspective on the current experience and to symbolize it. In this way they are instrumental to what it is really about: stimulating the experience of meaning in and from the conversation. The focus on this experience can be grounded and stimulated by the existential approach. Imagination and sensitivity to physical perception thus form an important contribution to the meaning-giving process, in addition to the authentic testimony of one's own spiritual inspiration. Interreligious spiritual care should be part of intercultural spiritual care, of which an analysis of the language is an important component.
\end{abstract}

\section{Probleemsituering}

In 2010 bracht de Nederlandse Bisschoppenconferentie het beleidsdocument Herkenbaar en betrouwbaar pastoraat uit als leidraad voor de geestelijke verzorging in de zorg, bij defensie en justitie. De bedoeling was duidelijk: verzekeren dat katholieke cliënten alsook katholieke medewerkers in deze drie sectoren altijd een beroep kunnen doen op katholieke geestelijk verzorgers. De reacties uit het veld waren verdeeld. Door de katholieke sector van de beroepsvereniging VGVZ en door bestuurders van zorginstellingen werd het document afgeserveerd als achterhaald. Bij justitie en defensie was men minder uitgesproken negatief; sterker nog, naar het document wordt nog steeds gerefereerd door medewerkers en beleidsmakers. De bisschoppen hebben het document nooit teruggetrokken maar ook niet geactualiseerd. De wijze waarop de betrokken partijen - de geestelijke verzorging in de werkvelden, hun besturen en natuurlijk de bisschoppen zelf - tegen het document aankijken, heeft alles van doen met hoe zij de godsdienstsociologische trends

* Wim Smeets is geestelijk verzorger, leersupervisor en UHD Innovatie in Spirituele Zorg in het Radboudumc. 
interpreteren, d.w.z. hoe zij de neergang van het toebehoren tot levensbeschouwelijke instituties beoordelen. Ofwel wordt de verminderde relevantie ervan benadrukt, ofwel wordt op de nog steeds aanzienlijke groep mensen gewezen die zich als kerkelijk beschouwt. Afgezien daarvan schuilt er ook een visie achter op het gesprek over zin en levensbeschouwing door geestelijk verzorgers en hun gesprekspartners, namelijk over de al dan niet bepalende rol van geloofsopvattingen in dat gesprek.

De actuele discussie over interreligieuze geestelijke verzorging spitst zich toe op de vraag welke kennis van de levensbeschouwing van de cliënt noodzakelijk of voldoende is voor de begeleider. Afhankelijk van het antwoord op die vraag pleiten auteurs in het veld van de geestelijke verzorging voor begeleiding door een geestelijk verzorger die dezelfde levensbeschouwing als de cliënt heeft of achten zij begeleiding door een geestelijk verzorger met een andere levensbeschouwing heel goed mogelijk. De waardering voor bepaalde strategieën in het gesprek kan ook tegen deze achtergrond begrepen worden. In haar proefschrift bespreekt Anke Liefbroer (2020) twee van dergelijke strategieën: neutraliseren en 'code-switching'. In het eerste geval is basale kennis van de levensbeschouwing van de ander voldoende om een aantal generieke overeenkomsten inzake achtergrond en overtuigingen te delen. In het tweede geval is meer kennis nodig om de beleving van cliënten te kunnen begrijpen en te duiden vanuit concepten en visies van hun levensbeschouwing. Maar om dat echt goed te kunnen doen, moet je die levensbeschouwing zelf ook van binnenuit kennen, zeggen de voorstanders van de zogenaamde categoriale werkwijze. Dan hoef je geen gebrekkige code-switching te doen. Bovendien wijzen zij op de betekenis van het ambt van de geestelijk verzorger. Dat is in de eerste plaats gericht op het faciliteren van het gesprek over levensbeschouwing tussen gesprekspartners die dezelfde traditie delen; het ambt is immers verleend door een bepaald genootschap en heeft vooral symbolische betekenis voor mensen die zich tot dat genootschap rekenen. Daarbinnen komt het persoonlijk getuigenis, waarvoor Aad de Jong (2019) in zijn postuum verschenen boek pleit, het meest tot zijn recht. Op die manier heeft ook Huijzer (2018) de 'attestatie' als een synoniem van getuigenis - een begrip van Ricoeur - blootgelegd in het werk van protestantse geestelijk verzorgers. Het ambt en het persoonlijk getuigenis kunnen natuurlijk ook door anderen herkend worden, maar vanuit institutioneel opzicht geldt deze symboolfunctie in eerste instantie voor de leden van het eigen genootschap.

Waar deze beschouwingen aan voorbijgaan is dat het gesprek met cliënten in de eerste plaats niet gaat over levensbeschouwelijke inhouden. Het startpunt voor gesprek is praktisch altijd datgene wat de cliënt nu bezighoudt. 
Deze actuele beleving loopt als een rode draad door het gesprek, vanaf het begin tot aan het einde. De grote uitdaging voor de gespreksbegeleider is om de ander bij te staan in de betekenisgeving aan deze actuele ervaring. En voor deze betekenisgeving kunnen tal van zingevings- en inspiratiebronnen gehanteerd worden - klassiek levensbeschouwelijke, maar nog vele andere. Naarmate opgroeiende generaties minder gesocialiseerd worden in de godsdiensten en georganiseerde (bovenindividuele) levensbeschouwingen, zullen andere culturele bronnen aan belang winnen. ${ }^{1}$

In mijn bijdrage wil ik laten zien hoe zingeving zich in het begeleidingsgesprek ontvouwt. De centrale vraag is: Hoe kan ik als begeleider de ander helpen om hier en nu - in dit gesprek - zin te ervaren? Deze vraag bevat vier elementen: de begeleider, de ander, het helpende gesprek en de ervaring van zin. Deze elementen zal ik telkens aan de hand van literatuur verhelderen. In het eerste deel van deze bijdrage zal ik me richten op het laatste element van deze vraag, het ervaren van zin. Na een korte illustratie van hoe het fenomeen zin in onze samenleving verschijnt, wordt theoretische verdieping gezocht in het ervaren van zin. De sub-vragen die ik daarin zal trachten te beantwoorden zijn: Hoe verhoudt zinervaring zich tot zingeving, welke vermogens worden hierbij aangesproken en wanneer worden mensen uitgedaagd tot een nieuwe ervaring van zin? Vervolgens wordt het voorlaatste element van de vraagstelling bekeken: het gesprek over zin. Hoe krijgt het proces van de zinervaring gestalte tijdens het gesprek? Tenslotte komen de gesprekspartners aan de orde. Wie is de ander en wat betekent het als die ander een andere cultuur en levensbeschouwing heeft dan de begeleider? En wie is de begeleider? Wat is haar of zijn rol in het gesprek in het algemeen en in het interlevensbeschouwelijk gesprek in het bijzonder? Van daaruit wordt gepoogd aan zingevingsbegeleiders adviezen te geven over hun rol in het proces van het gesprek en worden aanbevelingen geformuleerd voor scholing en onderzoek.

Ik zal me in deze bijdrage beperken tot de belangrijkste, recente literatuur op gebied van zingeving zonder de pretentie volledig te willen zijn. Tevens zal ik me praktisch uitsluitend richten op de inzet van geestelijk verzorgers bij het gesprek over zingeving. De noodzakelijke afstemming van hun inzet op die van andere professionals en de meerwaarde daarvan zullen buiten beschouwing blijven. ${ }^{2}$ 


\section{Een zinvol leven}

In diverse media wordt over zin geschreven en gesproken. Zingeving is 'in'. Het blijkt zich op velerlei wijzen te manifesteren. Een mooi voorbeeld zijn de artikelenseries over zingeving in dagbladen als Trouw en De Volkskrant. "Ik heb lang geworsteld met het idee dat je een ander pas kunt helpen wanneer je jezelf eerst hebt geholpen. Eerlijk gezegd geloof ik dat niet. Mijn beweging naar de ander is in ieder geval niet het gevolg van diepe zelfreflectie, maar komt simpelweg voort uit de aandrang om die stap te maken. Gaandeweg ben ik me gaan realiseren dat die zin geeft aan mijn bestaan." Zo beschrijft Geeske Hovingh - coördinator van het Wereldhuis, een door protestantse kerken opgericht centrum voor ongedocumenteerde vluchtelingen - wat voor haar een zinvol leven is. Net als een aantal andere maatschappelijk geëngageerde personen werd zij geïnterviewd door Fokke Obbema voor zijn nieuwe serie over een zinvol leven in het dagblad Trouw. Eerder had hij voor diezelfde krant al een serie gewijd aan de beleving van de dood. In een pendelbeweging om zowel navelstaarderij als een loutere gerichtheid op anderen te ontwijken, komt voor Hovingh het contact met de ander op de eerste plaats. Ze sluit zich aan bij Emmanuel Levinas die formuleerde dat 'ik word in het aangezicht van de ander'. Hovingh heeft het contact met de ander nodig om zin te kunnen geven aan haar bestaan. Ze moet dus, vanuit het Wereldhuis als haar werkcontext, anderen actief opzoeken om zin te kunnen geven aan haar werk en leven. Of zou je moeten zeggen dat ze zin ervaart wanneer ze anderen helpt hun gevoel van eigenwaarde te versterken?

Jarenlang probeerde Cuong Lu als monnik in een boeddhistisch klooster zich verder te ontwikkelen. Maar het lukte hem niet, en meer en meer voelde hij zich opgesloten, totdat hij het klooster verliet.

"In oktober 2010, ruim een jaar na mijn uittreden, deed ik weer een oefening om de positieve kwaliteiten van mijn bewustzijn te ontwikkelen. Maar ik voelde ik me zo hopeloos dat ik dat streven losliet en ging slapen. Midden in de nacht werd ik wakker en had ik voor het eerst van mijn leven plots contact met rust. Ik zag ineens: je bent als mens niet goed, maar ook niet slecht, je bent niet je bewustzijn! Daarmee raakte ik mijn essentie aan. Twintig minuten lang voelde ik een volkomen helderheid, rust. Ik was zo blij. Toen belde mijn vriendin, nu mijn vrouw, vanuit Hongkong. Ze vroeg: wat is er aan de hand? Ze voelde iets. Ik zei: 'Het is ongelofelijk, ik ben vrij schat. Ik ben goed noch slecht.' Het ontroert mij nu nog, nu ik dit vertel. Het is zo'n lange zoektocht geweest." In dit interview - weer opgetekend door Fokke Obbema - 
komt de verhouding tussen zingeving en zinervaring duidelijk naar voren. Jaren van actief proberen zin te maken door de oefeningen in het kloosterleven bleven op één of andere manier zonder resultaat. Dat 'resultaat' diende zich onverwacht aan in de slaap. Het was een ervaring die hem overweldigde en zelfs - volgens zijn relaas - tegelijkertijd ook zijn vriendin aan de andere kant van de wereld.

Cuong $\mathrm{Lu}$ is niet de eerste en enige die een eenmalige gebeurtenis als keerpunt in zijn leven beschrijft. Nogal wat van dergelijke beschrijvingen hanteren een typerend narratief. Voorafgaand aan de ommekeer is een lange periode van vruchteloze activiteit van de hoofdpersoon. Dan volgt een ervaring van verandering die gekenmerkt wordt door totale passiviteit van de hoofdpersoon. Deze kan enkel ontvangen wat haar of hem vanuit een transcenderende werkelijkheid wordt geschonken. Het is - in theologische termen - genade, of - in godsdienstpsychologische termen - een ervaring die kenmerken heeft van een bekering. Het leven krijgt van dan af een andere zin. Daarbij is de ommekeer-ervaring het bepalende referentiepunt van waaruit alle handelingen en gebeurtenissen geïnterpreteerd worden.

Voor heel veel mensen blijft deze ervaring vreemd. Soms klinkt het hen ook verdacht, wereldvreemd. We weten niet of dat voor Hovingh ook geldt. Met een zeker cynisme vertelt ze over het eigen zoeken naar zin: "Ik ben niet iemand die zich met een mandala-schrift in een klooster terugtrekt." Voor deze mensen is zin iets wat vooral gedaan moet worden in het leven van elke dag. Piekervaringen vallen hun zelden of nooit ten deel. Maar daar gaat het hen ook niet om. Het verschil tussen zinloosheid en zinvolheid wordt gemarkeerd door het eigen handelen en de betekenis die daaraan wordt toegekend. En dat vraagt een permanente oriëntatie in plaats van een eenmalig gebeuren.

Deze twee interviews uit de artikelenserie van Obbema illustreren de elementen uit onze vraagstelling. Als we kijken naar de gesprekspartners, dan valt het volgende op: er zijn er die bewust hun zingeving aan het bestaan aan de orde stellen, bij anderen blijft dat veel meer impliciet. Als we kijken naar de ervaring van zin, dan valt het volgende op: deze blijkt nu eens meer gekoppeld te worden aan het dagdagelijks leven en handelen als geheel, dan weer wordt ze verbonden met een welbepaald moment of situatie. Het begeleidingsgesprek: de focus ligt niet zozeer op het verhaal van mensen op zich, maar op de betekenis die zij toekennen aan gebeurtenissen en handelingen, waardoor het gesprek een meer beschouwend karakter krijgt. Kijken we naar de begeleider, dan zouden we kunnen zeggen: wat haar of hem kenmerkt is een attitude van 
openheid en interesse voor de zingeving van hun medemensen, met daaraan gekoppeld inzicht in de mogelijke variatie en individuele inkleuring van deze zingeving. Met deze twee voorbeelden zijn een aantal aspecten van de elementen in de vraagstellingen belicht. In het navolgende worden zij verder uitgewerkt. Begonnen wordt met de verheldering van de begrippen zingeving en zinervaring.

\section{Zingeving en zinervaring - theoretisch}

In deze paragraaf richt ik me op het element 'ervaren van zin', met de subvragen: hoe verhoudt zinervaring zich tot zingeving en welke vermogens worden hierbij aangesproken? Op die vraag wordt ingegaan door Hans Alma en Adri Smaling in hun - zeker in humanistisch Nederland baanbrekend - werk Waarvoor je leeft. Studies naar humanistische bronnen van zin (2009). In het eerste hoofdstuk van het boek doen zij een conceptuele verkenning van o.a. het begrip zingeving. Zingeving omvat alle aspecten van het menselijk functioneren: een cognitief, affectief, evaluatief, habitueel en handelingsaspect. Het cognitieve aspect betreft het denken van mensen, waarin ze betekenis geven aan dingen en gebeurtenissen; het leidt tot opvattingen, vaak op basis van kennis van levensbeschouwingen. Het affectieve aspect betreft de gevoelens van mensen inzake hun zingeving, positieve of negatieve gevoelens, gevoelens met betrekking tot zichzelf en tot anderen. Het evaluatieve aspect heeft betrekking op de waarden en normen van waaruit mensen wat zich afspeelt in hun leven interpreteren. Het habituele aspect heeft betrekking op de praktijken en rituelen waaraan mensen betekenis ontlenen of waarin ze deze betekenis tot uitdrukking brengen. Het handelingsaspect heeft betrekking op de het samenleven met anderen, wat ze alleen of met elkaar doen, de rollen en taken die ze in de maatschappij op zich nemen. Daarnaast is er ook sprake van zin-beleving. Met dat begrip richt men zich vooral op het affectieve aspect dat ook lichamelijk ervaren wordt. Daarnaast wordt de esthetische ervaring ook gekoppeld aan zinbeleving. Het zingevingsproces activeert niet enkel het verstand, maar net zo goed de verbeelding.

In haar onlangs verschenen boek Het verlangen naar zin. De zoektocht naar resonantie in de wereld (2020) herneemt Alma de poging tot verheldering in de terminologie. Om te beginnen valt op dat zij nu de twee termen zingeving en zinbeleving niet langer hanteert. Liever dan van zingeving te spreken, gebruikt zij nu de uitdrukking 'verlangen naar zin', wat ook meteen de titel 
van haar boek is. Door het gebruik van deze ene term wil zij het proces als geheel beschrijven. En ik heb de indruk dat ze in dat proces vooral het perspectief beklemtoont van wat ze eerder met zinbeleving aanduidde. Ik volg even haar gedachtegang. Het is het zelf dat naar zin verlangt, aldus Alma, door zich te oriënteren in ruimte en tijd. Dat proces beschrijft ze in eerste instantie niet als een cognitief gebeuren, maar als iets dat vertrekt vanuit onze lichamelijke gewaarwording. Daarmee bedoelt zij een bewustwording op basis van zintuiglijke indrukken: wat mensen voelen, proeven, ruiken, horen en zien. Deze bewustwording stimuleert de hogere waarneming, dat wil zeggen het interpretatieproces. Op die manier wordt de verbeelding van mensen geactiveerd. Het persoonlijk verbeelden vindt plaats binnen de context van tal van verhalen uit levensbeschouwingen (Alma spreekt van levensverkenningen). Die verhalen zijn getuigenissen van wat het leven waardevol maakt en staan in schril contrast met lijden en onrecht in het persoonlijke en publieke domein. Op die manier wil Alma nu van de aspecten die ze eerder onderscheidde vooral het evaluatief-ethische aspect naar voren halen en ook de esthetische component (die ze eerder met zinbeleving verbond). Volgens Alma geschiedt dat zin zoeken vooral en bij uitstek spontaan en ongedwongen, net als een spel.

In het proces van zingeving, het verlangen naar zin, zijn er echter ook momenten van zin-ervaring, waarin men even samenvalt met datgene waarop men gericht is. Deze zinervaring kan kort en vluchtig zijn: men gaat op in gewone bezigheden. Deze zinervaring kan ook beslissend zijn voor het verdere levensverloop wanneer het gaat om zogenaamde mystieke momenten. Dergelijke zinervaringen zijn mogelijk doordat men nauw betrokken is op zichzelf, de wereld en de natuur om zich heen - waarmee men bijna verstrengeld raakt in een wederkerige dynamiek. Alma besluit haar boek met een beschouwing van de liefde, die bij uitstek een relatie van resonantie veronderstelt. De liefde berust op het plotselinge besef dat de ander bestaat. In de liefde kunnen we soms een glimp opvangen van het ongrijpbare goede en genieten van rust en vrede. En zo heeft het boek, dat hoofdzakelijk het stempel draagt van een actieve gerichtheid - er moet nogal wat gedaan worden voor de zinvinding ook aandacht voor de receptieve ervaring van zin.

Op de vraag welke menselijke vermogens bij zingeving en zinervaring een rol spelen is het antwoord van Alma niet veranderd. Het meest belangrijk is de verbeelding (Alma \& Smaling 2011; Alma 2020). Daarmee sluit zij ook nauw aan bij haar collega aan de Universiteit voor Humanistiek, Jan Hein Mooren. 
Mooren heeft in zijn synthesewerk Verbeelding en bestaansoriëntatie (2011) de verhouding tussen zingeving en verbeelding theoretisch en praktisch doordacht. Theoretisch legt hij vanuit de filosofie en psychologie een verbinding tussen enerzijds de wijze waarop de mensen zin geven aan hun bestaan met zichzelf, anderen en de wereld en anderzijds verschillende typen van verbeeldingsactiviteiten (dromen, illusies, metaforen, utopieën). Praktisch bespreekt hij allerlei methoden waarin zingevende verbeeldingsactiviteiten gestimuleerd kunnen worden: supervisie en coaching, training, geestelijke verzorging en moreel beraad.

Dat voor wat betreft de rol van de verbeelding. Impuls voor de inzet van verbeeldingskracht vormt meestal de bewustwording vanuit zintuiglijke indrukken, een lichamelijke gewaarwording. Op de ontwikkeling en stimulering van dat vermogen kom ik in de volgende paragraaf terug. Cognitieve activiteiten, zoals het verwerven van inzicht in levensbeschouwingen, hebben een ondergeschikte, dienende plaats. Wil een begeleider het bezig zijn met zingeving bij anderen stimuleren - het vertrekpunt van mijn bijdrage - dan moet hij dus niet in de eerste plaats denken aan het overdragen van en bespreken van kennisinhouden. Zingeving kan echter wel degelijk gestimuleerd en ontwikkeld worden in begeleidingsinteractie, maar dan vooral gericht op het gebruik van de verbeelding.

Vooraleer ik dieper inga op de wijze waarop dat in deze interactie kan plaatsvinden, ga ik nog nader in op het ervaren van zin. Wat wordt er dan precies ervaren? Op basis van Alma en Mooren onderscheid ik een aantal elementen daarin. En hoe komt het ervaren van zin tot stand? Over het scheppen van de condities daartoe, is meer te vinden in de spiritualiteitsstudies. Vanuit de existentiële benadering binnen filosofie en psychologie werk ik uit dat ons menselijk bestaan in tijd en ruimte op zich al de basisconditie schept. Ik sluit mij aan bij de existentiële psychologie omdat daar aan intrapsychische processen bij het ervaren van zin ruime aandacht wordt geschonken.

\section{Zinervaring nader beschouwd}

Eerst richt ik me op de elementen van het ervaren van zin. Mooren onderscheidt vijf aspecten van wat hij het zingevingskader noemt wereldbeeld, levensperspectief, ethiek, mens- en godsbeeld en leefregels. Aan elk aspect van dat kader koppelt hij een element van de zinervaring. Alma en Smaling 
spreken van negen elementen - vier meer dus. Ik voeg beide indelingen samen en overloop ze kort. Aan het wereldbeeld is de ervaring van begrijpelijkheid of samenhang (1) gekoppeld: een wereldbeeld biedt eenheid tussen losse elementen van de werkelijkheid die dan als zodanig als inzichtelijk wordt ervaren. Een levensperspectief is gekoppeld aan de ervaring van betrokkenheid (2) en aan de ervaring van doelgerichtheid (3). Betrokkenheid betreft de motivatie om je leven vorm te geven. Doelgerichtheid betreft ofwel concrete streefdoelen ofwel een algemene oriëntatie, een richting. Waarden en normen zijn verbonden met de ervaring van waarde-volheid (4) en met de ervaring van gemoedsrust (5). Waardevolheid kan zowel betrekking hebben op iets wat in zichzelf waardevol is of iets wat bijdraagt tot iets van waarde. Gemoedsrust is de rust die je ervaart als je niets verkeerd hebt gedaan, als je leeft volgens je waarden en normen. Met een beeld van de mens en van God zijn de ervaringen van eigenwaarde of erkenning (6), de ervaring van verbondenheid (7) en de ervaring van transcendentie (8) gekoppeld. Eigenwaarde betreft de ervaring er toe te doen, als gelijkwaardig mee te tellen. Verbondenheid kan gaan van één of enkele relaties tot de wereldgemeenschap. Transcendentie heeft betrekking op de ervaring van het overstijgen van het hier-en-nu, het dagdagelijkse. Aan het kader van leefregels is de ervaring van competentie (9) gekoppeld. Daarmee wordt bedoeld het ervaren in staat te zijn tot adequaat handelen en controle te hebben over het leven. Er is geen noodzakelijke volgorde, dat wil zeggen wat het eerst komt en wat erna, kader of ervaring. Wanneer mensen één of meer van de voorgaande elementen ervaren, kan er sprake zijn van een gevoel van welbevinden.

Het volgende punt is dan hoe dit ervaren van zin, met de genoemde elementen, tot stand komt. Mystici zijn door de eeuwen heen op zoek geweest naar een welbepaalde ervaring van zin, namelijk de ervaring van transcendentie - concreet de ervaring van de aanwezigheid en contact met een Opperwezen. Maar een mystieke ervaring kan eveneens betrekking hebben op de aanwezigheid en contact met de natuur, de kosmos of de mens zelf. In spiritualiteitsstudies worden de beschrijvingen van die religieuze of gelijkaardige ervaringen bestudeerd. Niet enkel het element transcendentie is object van studie, maar ook andere genoemde elementen van zin komen aan de orde; eerder noemden we dat een beeld van God ook gekoppeld is aan de ervaring van erkenning en verbondenheid. Ook wordt in die studies aandacht besteed aan de voorwaarden om een dergelijke ervaring mogelijk te maken. Daarbij gaat het om zaken als afzondering, stilte, voortdurend gebed of meditatie, armoede, gehoorzaamheid, al dan niet afzien van seksualiteit enz. Het kader 
van deze leefregels is gekoppeld aan de ervaring van competentie, van zelfcontrole.

Daar waar de spiritualiteitsstudies zich hebben verdiept in levenswijzen als voorwaarden om tot een bepaalde ervaring van zin te komen, kiest het existentialisme een andere weg. Deze benadering in de filosofie brengt naar voren dat de 'condition humaine' als zodanig de mens tot een ervaring van zin voert, in negatieve dan wel in positieve zin. Volgens Kierkegaard is angst een fundamentele ervaring die de mens kan kwellen. Mensen zijn eenzaam in een werkelijkheid die vaak als absurd wordt ervaren. Sartre en De Beauvoir zijn de belangrijkste spreekbuizen van deze visie. Een meer positieve betekenis van het mens-zijn en de werkelijkheid - met een erkenning van een goddelijke transcendentie - vinden we in het werk van onder meer Tillich. Hij heeft het existentialisme ook een belangrijke plaats gegeven binnen de theologie.

De existentiële benadering binnen de sociale wetenschappen komt inhoudelijk sterk overeen met die van de filosofen en theologen, maar meer gesystematiseerd. Volgens Leijssen (2001; 2006; 2007) speelt het 'existing', het 'in-de-wereld-zijn' (in het kader van ruimte en tijd) zich af in vier dimensies: een fysieke, een psychologische, een sociale en een zingevingsdimensie. Inzake die laatste dimensie heeft Yalom (2012) vier existentiële zingevingsthema's onderscheiden. Het eerste thema is de eindigheid: we leven in de tijd die uitloopt op de dood. Het tweede thema is de vrijheid: we kunnen kiezen en zijn daardoor ook zelf verantwoordelijk voor onze keuzes. Het derde thema is de fundamentele eenzaamheid: in ons streven naar verbondenheid worden we telkens weer teruggeworpen op onszelf. Het vierde en laatste thema is de ultieme zinloosheid: al onze pogingen tot zingevingen worden bedreigd door uitzichtloosheid. Existentiële therapie betekent begeleiding van cliënten om zin te ervaren bij deze thematieken. Eén van de grondleggers ervan is Frankl (1979), die de logotherapie ontwikkelde; vanuit zijn persoonlijke geschiedenis - in een concentratiekamp - is hij optimistisch inzake het vermogen van mensen om in alle omstandigheden toch zin te kunnen ervaren. Deze optimistische benadering vinden we eveneens terug bij andere vertegenwoordigers van de existentiële therapie. Moustakas (1979) bijvoorbeeld beschrijft hoe eenzaamheid, het derde genoemde thema, kan leiden tot de ervaring van verbondenheid. Het open staan voor het ervaren van zin inzake de genoemde thema's is volgens de auteurs in de existentiële benadering een synoniem van authentiek bestaan. 
In de existentiële benadering vinden we tevens een uitwerking van wat we eerder het startpunt van veel zingevingsactiviteit hebben genoemd: de lichamelijke gewaarwording. En er wordt ook ingegaan op hoe dit vermogen ontwikkeld kan worden. De existentiële psychologen gaan er namelijk vanuit dat het echte contact met het existentieel ervaren begint met het aandacht geven aan wat impliciet aanwezig is in het lichamelijk gewaarworden, dat gekoppeld is aan het eigen gedrag en de interacties met anderen. Leijssen spreekt in dit verband van het ervarende lichaam ('sensed from inside') in tegenstelling tot de lichaamstaal die van buitenaf waar te nemen is, het lichaam dat in beweging is en het lichaam dat aangeraakt wordt. In het contact is de begeleider niet enkel gericht op de gedachten en gevoelens die geuit worden, maar ook op deze lichamelijke ervaringen. Alleen dan kan een werkklimaat gecreëerd worden, waarin de gesprekspartner ervaart er als gehele mens te mogen zijn. Gendlin (1998) ontwikkelde de methode van 'focusing'. Het begeleidingsproces vindt, zo meent hij, plaats door telkens nieuwe lagen van dat (impliciet) ervaren naar boven te halen en te verbinden met taal of andere symbolische expressievormen. Zo wordt voorkomen dat mensen alleen maar gaan praten over de zin die zij denken te ervaren. Het spreken wordt een spreken vanuit de ervaring van het bestaan, dat in eerste instantie pre-conceptueel, ongedifferentieerd en lichamelijk van aard is. Daartoe is stilte, bewustwording van de lichamelijke gewaarwordingen nodig. De existentiële benadering gaat ervan uit dat een mens zin kan ontwikkelen door het doorlopen van het net genoemde proces. Dat impliceert dat ook in de begeleidingsinteractie een dergelijk authentiek proces van zinervaring doorlopen moet worden.

De ervaring van zin is hierboven gedifferentieerd naar negen elementen. In de existentiële benadering werd een wetenschappelijke verdieping van deze invalshoek in de dynamiek van het proces van zin geven en zin ervaren aangetroffen. Daar waar de mystiek zich vooral gericht heeft op de ervaring van transcendentie, erkenning en verbondenheid hebben de filosofische en theologische existentialisten zich vooral gericht op angst, eenzaamheid en verantwoordelijkheid. In de sociale wetenschappen is de scope verbreed naar alle dimensies van het menselijk bestaan. De methode van 'focusing' biedt meer zicht op hoe het ervaren kan worden gestimuleerd, vertrekkend vanuit de lichamelijke gewaarwording. Als het gaat over 'meaning making' dan gaat het hier om een andere benadering dan de repliek van René Gude destijds toen men hem vroeg: 'Welk antwoord geef je mensen die zeggen: ik heb geen zin?' 'Dan maak je maar zin.' Hij bedoelde het zelf natuurlijk ook genuanceerder, maar zin kan je niet zomaar creëren met je wil en je verstand. Aan 
de hand van de existentiële benadering is verduidelijkt hoe het ervaren van zin dan wel tot stand kan komen. Een situatie waarin mensen bijzonder uitgedaagd worden om tot nieuwe zin te komen, is de crisissituatie. We gaan er in de volgende paragraaf apart op in, omdat geestelijk verzorgers en andere zingevingsbegeleiders mensen vaak in een dergelijke situatie ontmoeten. Alle menselijke vermogens zijn in het geding en een receptieve ervaringsmodus is onontbeerlijk. Dat is met name van belang wanneer we kijken naar zingeving in crisissituaties.

\section{Zinervaring in crisis}

Vanuit wat mensen in het leven meemaken hebben zij een min of meer expliciet geheel aan opvattingen en waarderingen dat hun kijk op henzelf en hun handelen met anderen in de wereld vorm geeft. Park \& Gutierrez (2013) noemen dat 'global meaning'. Wanneer er zich echter een 'life event' voordoet kan de mens daarmee niet volstaan. Dergelijke events kunnen positieve gebeurtenissen zijn, zoals verliefdheid, het krijgen van een kind, het afronden van een studie, het krijgen van een baan of promotie. Ook bij negatieve gebeurtenissen zoals het verlies van een dierbare, een scheiding, ontslag, een justitiële veroordeling en een gezondheidscrisis kan een mens er meestal niet omheen: er moet betekenis gegeven worden aan deze nieuwe levenssituatie. Er is een discrepantie ontstaan tussen de tot dan toe geldende zingeving met de nieuwe gebeurtenis of toestand. In dat geval spreken Park \& Gutierrez van de uitdaging tot 'situational meaning'.

Park \& Gutierrez hebben duidelijk gemaakt dat 'global meaning' vaak ontoereikend is bij een levenscrisis. In het proces dat leidt tot de 'situational meaning', hebben verschillende auteurs inzicht proberen te verschaffen, vooral uit het veld van de geestelijke verzorging - die zoals gezegd vaak bij crisissituaties wordt ingeschakeld. Twee auteurs die recent een poging daartoe hebben gedaan zijn De Ceuninck van Capelle (2017) en Van Dalen (2019). Eerstgenoemde auteur onderzocht de ervaringen met ziekte en het dagelijks leven van MS-patiënten. Hij spreekt van geleefde ervaringen als aanvulling op de objectiverende benadering in de geneeskunde. Zijn bevindingen sluiten naadloos aan bij hoe er hiervoor over de zinervaring werd gesproken. De patienten vertellen over hoe ze hun klachten - zintuiglijk - voelden: verminderd zicht, zwalkende of dove ledematen; het horen van de diagnose is een ervaring die ze nooit meer vergeten. Allen beschrijven een verscherpte waarne-

Religie a Samenleving, Jrg. 15, nr. 3 (december 2020) 
ming van zichzelf, anderen en hun omgeving. In hun relaas zijn ruimtelijke en tijdelijke metaforen te onderkennen - de rol van de verbeelding - : 'er nog niet klaar voor zijn', 'een drempel over moeten' enz. Er is een andere ervaring van het levensperspectief en de verbondenheid met anderen, met niet zelden schaamte- en schuldgevoel. Niet alleen in het dagelijks leven verandert de competentie-ervaring, maar ook inzake de deelname aan het arbeidsproces. De Ceuninck van Capelle pleit voor het toepassen in onderzoek van de fenomenologische methode, ontwikkeld door Husserl - één van de grondleggers van het existentialisme. Op die manier wordt de stem van de ervaring uitgangspunt van waarneming en analyse.

Van Dalen onderzocht de betekenisgeving van mensen die de ingrijpende diagnose 'kanker' hebben gekregen. Uit de analyse van zijn interviews kwam naar voren dat mensen met de rug tegen muur soms een ervaring hebben van zin die hen wordt aangereikt. Hij spreekt van de gewaarwording van 'het open andere'. ${ }^{3}$ Hij onderscheidt vier typen van dergelijke ervaringen. Ten eerste is er de allocentrische ervaring, waarin de mens verwijlt bij de verbondenheid die hem door het andere wordt aangereikt. Dat kan een ervaring in contact met andere mensen zijn, maar ook een natuurervaring bijvoorbeeld. Ten tweede is er de anomale ervaring, waarin men iets ervaart wat buiten de horizon valt van wat men normaal voor mogelijk houdt. Dat kunnen bizarre ervaringen zijn, maar ook voor veel buitenstaanders vreemde ervaringen als bijna-doodervaringen, dromen, esoterische ervaringen. Ten derde is er de ervaring van synchroniciteit, waarin iemand aan het tegelijkertijd voorkomen van dingen een bijzondere betekenis toekent. Het samen voorkomen van dingen kan niet causaal verklaard worden maar wordt niet als toeval gezien. Tenslotte, enigszins apart, is er de ervaring van de levensweg. De mens beschouwt de voorbije tijd van op afstand en ziet er een rode draad in. Al deze ervaringen doen zich aan de mens voor, ze zijn een mooi voorbeeld van het startpunt van zingeving vanuit de lichamelijke gewaarwording in relatie tot het eigen handelen en leven met anderen (cfr. Gendlin 1998). Deze gewaarwordingen van 'het open andere' leiden op één of andere manier tot een transformatie van het verhaal dat mensen over zichzelf vertellen. De unieke ervaring wordt ingeweven in de betekenis die zij aan het eigen leven toekennen.

Wanneer mensen deze ervaringen delen, kan daardoor ook de zingeving van hun gesprekspartner beïnvloed worden, tenminste als deze zich ervoor open stelt. De 'situational meaning' van de mens in crisis krijgt weerslag op de 'global meaning' van de gesprekspartner, het verruimt dus het perspectief 
van beiden. Giebner (2015) heeft onderzocht wat zorgverleners ontvangen van hun cliënten. Uit haar onderzoek bleek dat zorgverleners niet enkel geven aan hun cliënten, maar ook iets terugkrijgen. En dan gaat het over de betekenissen die mensen in grote nood aan hun situatie geven, over de kracht die zij soms ten toon spreiden. ${ }^{4}$ De ervaringen van direct en nauw contact met hun cliënten kan voor de zorgverleners bijdragen tot nieuwe oriëntaties en nieuwe betekenisgevingen. Vanuit deze optiek worden in het Maastrichts Universitair Medisch Centrum door de geestelijke verzorging groepstrainingen 'zin in je werk' voor zorgverleners georganiseerd, waarin ze zulke ervaringen uitwisselen. Groepssessies met professionals en cliënten samen zijn al langer gemeengoed in de gezondheids- en welzijnszorg. Cliënten worden dan 'ervaringsdeskundigen'. Op deze manier wordt zinervaring een gedeeld gebeuren.

Een crisissituatie daagt uit tot 'situational meaning'. De ontmoeting tussen zorgverlener of welzijnswerker en een cliënt draagt idealiter bij tot het ontwikkelen van deze 'situational meaning'. Hoe kan het gesprek een nieuwe ervaring van zin faciliteren, of nog sterker, die ervaring bewerkstellingen? Omdat geestelijk verzorgers bij uitstek gevraagd worden voor een dergelijke begeleiding, wil ik deze vraag beantwoorden aan de hand van de theorievorming over het gesprek van geestelijk verzorgers. Daarbij komt dan nog een extra vraag om de hoek kijken in het licht van de traditionele nadruk in hun werk op levensbeschouwelijke overtuigingen en praktijken: hoe zien zij de rol van levensbeschouwelijke overtuigingen en praktijken? Bevorderen die het ontdekken van nieuwe zin of vormen ze daartoe een belemmering?

\section{Zinervaring tijdens gesprek}

Hoe kan je het ervaren van zin tijdens het begeleidingscontact zelf stimuleren? Om die vraag te beantwoorden bespreek ik de belangrijkste pogingen van praktisch theologen in het Nederlandse taalgebied die - in dialoog met elkaar - daarop zicht hebben proberen te krijgen.5 Johan Smit (2006) was één van de eerste praktisch theologen in het Nederlands taalgebied die daarvoor een gespreksmodel heeft ontwikkeld. In feite is het een lagenmodel, om tijdens én na het gesprek na te gaan 'op welke laag in de communicatie' je als begeleider bezig was. Smit onderscheidt vier lagen: feiten, gevoel, levensbeschouwing en spiritualiteit. 'Tot de kern komen' betekent volgens hem dat je vanuit het niveau van de feiten doorstoot naar de persoonlijke spiritualiteit 
van je gesprekspartner. De dynamiek van het gesprek ontwikkelt zich volgens Smit op die manier 'van buiten naar binnen en weer terug'. Later heeft Smit (2011) zich gespecialiseerd in de communicatie vanuit geestelijke verzorging en pastoraat met mensen met een beperking. Daar vraagt het doorstoten in het gesprek naar diepere lagen, voorbij de feiten, om specifieke deskundigheid.

Het model van Johan Smit is vele jaren het toonaangevende model geweest in onderwijs en supervisie binnen het veld van de geestelijke verzorging. De kracht ervan lag in de visualisering van wat 'tot de kern komen' in het gesprek betekent. Wellicht daarom ook refereren nog steeds veel geestelijk verzorgers aan dit model om aan te geven waar hun gesprekken over gaan. Maar hoe je als begeleider de dynamische ontwikkeling naar de zogenaamde spirituele kern stimuleert, daar biedt het model weinig inzicht in. Jaap Dijkstra heeft daartoe twee pogingen ondernomen (Dijkstra 2007; 2012). In zijn eerste boek richtte hij zich op de basale gespreksvaardigheden van de geestelijk verzorger, dat wil zeggen de vaardigheden die voorwaarde zijn om überhaupt naar de diepte te gaan. In zijn tweede publicatie (Dijkstra 2012) richt hij zich specifiek op de 'spirituele kern' zoals Johan Smit had aangeduid. Het boek is minder praktisch-theologisch en meer mystiek, aansluitend bij de eerder genoemde existentiële benadering. Het boek nodigt de lezer uit tot deelname aan deze ervaring van de werkelijkheid. De belangrijkste aanwijzing van Dijkstra voor gespreksbegeleiders is om zich blijvend te verwonderen over wat zij zintuiglijk waarnemen, zonder er meteen een analytisch oordeel aan te koppelen. En daarmee sluit hij aan bij wat we eerder zeiden over gewaarwording en verbeelding.

Kritiek op het lagenmodel van Johan Smit kwam van De Groot en Evers (2017). Zij stellen een cyclisch model voor, waarbij je start vanuit de beleving in het hier-en-nu. Die beleving is in eerste instantie een algemene ervaring, waarin feit en gevoel dicht bij elkaar liggen. Van daaruit wordt de betekenisgeving geëxploreerd in ruimte en tijd. De beleving wordt eerst verkend naar de context van de leefomgeving, dichtbij en verder af. Vervolgens wordt die beleving in historisch perspectief geplaatst. Hoe kan de beleving begrepen worden in het licht van eerdere ervaringen en betekenisgevingen? Vervolgens wordt de vraag gesteld hoe van hieruit gekeken kan worden naar de nabije toekomst, waarbij ook de overgang naar handelingsoriëntaties wordt gemaakt. Vanuit hun model is te beargumenteren om een gesprek niet te starten met de vraag 'hoe gaat het?' maar met 'wat houdt je bezig?' Zo sluit het gesprek meteen aan 
bij de actuele ervaring van zin. Ook verpleegkundigen worden nu uitgenodigd om hun gesprekken te richten op 'what matters to you?'.

Job Smit (2015) heeft als eerste een generiek basismodel voor geestelijke verzorging ontwikkeld. Daarbij gaat hij uit van een theoretische synthese van ongeveer alle literatuur over het vak tot en met het eerste decennium van deze eeuw. Vervolgens heeft hij dit model ter toetsing gelegd op een heel aantal gesprekken van collega's. Dat is ook de manier waarop hij de toepassing van zijn model voorstaat: als analyse-instrument achteraf, in supervisie en training. Hij komt uit bij een variant van het lagenmodel van zijn naamgenoot. Het gesprek start met naderen: verkenning van de beleving of hulpvraag van de gesprekspartner. Vervolgens wordt getracht verdieping aan te brengen. Dit gebeurt o.m. door het hanteren van de relatie, het vergroten van het perspectief van de ander en van daaruit het vinden van een nieuwe balans. Daarbij kan een beroep gedaan worden op duidingen vanuit levensbeschouwing en cultuur. Als dit verdiepen lukt, kan het gebeuren dat de gesprekspartner een nieuwe zin ervaart in datgene wat zij/hij meemaakt. De taak van de geestelijk verzorger is dan om terug te treden, het gesprek van de ander met zichzelf te laten gebeuren en hoogstens af en toe verder te stimuleren. Het gesprek vertraagt, de bewustwording van de gesprekspartner staat centraal. Vervolgens is wel de opdracht om het nieuw ontdekte te verbinden met de bredere realiteit: symbolisch verbinden met voorhanden zijnde zingevingsduidingen en verbeeldend te verbinden met de nabije toekomst die voor ligt. Tenslotte dient het gesprek te worden afgerond, formeel of ook wel ritueel - vandaar dat Smit spreekt over 'vieren'. Intussen is reeds een eerste poging ondernomen om de gespreksinterventies van de geestelijk verzorger in deze vijf fasen te identificeren, gebruikmakend van verschillende soorten interventie-typologieën uit de psychologie (Smit \& Smeets 2018). ${ }^{6}$ Daarmee krijgt de geestelijk verzorger concrete handreikingen voor de begeleiding van de zelfexploratie door de gesprekspartner. Het gesprek biedt ruimte voor de ervaring van zin.

Zoals eerder aangegeven beoefenen niet enkel geestelijk verzorgers zingeving in hun werk. Voor alle zingevingsprofessionals in zorg en welzijn is het van belang om in training en supervisie bewust stil te staan bij deze dimensie van hun begeleidingsgesprekken. Bevorder ik de zingeving van de ander of sta ik die juist in de weg? Is wat ik meen waar te nemen echt van de ander of projecteer ik mijn eigen interpretatiekader? Ook in scholing kan het ervaren van zin door supervisant of cursist plaatsvinden. Daar is in de literatuur over 
supervisie en (interprofessioneel) leren de laatste jaren meer aandacht voor gekomen (Smeets 2015; 2019).

De uitgangsvraag van deze paragraaf luidde: 'hoe kan je het ervaren van zin tijdens het begeleidingscontact zelf stimuleren?’ Het antwoord op die vraag komt erop neer dat een begeleider erop gericht moet zijn om vanuit de feiten en de gevoelens door te stoten naar de betekenisgeving die eronder ligt en naar de diepste kern - de existentie. Dat vereist van de begeleider zelf ook een dergelijke ervaring van de werkelijkheid en aandacht voor de lichamelijke gewaarwording, vanaf het begin van het gesprek. Zo wordt voorkomen dat het gesprek beperkt blijft tot een verhaal over de 'global meaning' van de gesprekspartner.

$\mathrm{Na}$ de beschouwing van het zingevingsgesprek wil ik een voorlopige balans opmaken. Waarom is het bevorderen van de zinervaring tijdens het gesprek zo belangrijk? Het eerste antwoord ligt in de actuele behoeften van de client. Bij een crisissituatie kan een mens aan de grenzen van de bestaande zingeving komen en is nieuwe 'situational meaning' noodzakelijk, zoals De Ceuninck van Capelle dat beluisterden bij MS patiënten. Dan kan het creëren van ruimte, openheid voor nieuwe zinervaring heilzaam zijn. Maar natuurlijk is dit niet enkel aan de orde wanneer er zich een crisis voordoet en zo komen we bij het tweede antwoord. De existentiefilosofen en - psychologen hebben ons bewust gemaakt van de permanente staat van angst die mensen dwingt tot zingeving in het aangezicht van tijd, vrijheid, eenzaamheid en zinloosheid. Volgens Leijssen is het essentieel dat we permanent ermee bezig zijn om onze krachtbronnen op lichamelijk, psychisch, sociaal én spiritueel vlak te onderhouden en te versterken. Daarbij hoort dus ook het bezig zijn met onze dagelijkse en ultieme zingeving. Zo dragen we bij tot integrale, positieve gezondheid in al haar facetten.

Zingevingsprofessionals zijn gericht op versterken van het gezonde deel van mensen, veeleer dan op het oplossen van problemen. Uiteindelijk - en dat is het derde antwoord - reikt het ervaren van zin echter verder dan een instrumenteel doel, het is - in de woorden van Alma - een verlangen. Het geluk in en de zin van ons leven heeft alles van doen met het hebben van ontmoetingen die verdiepend en deugddoend zijn. Zo getuigde ook Geeske Hovingh aan het begin van dit artikel. Het is mooi om daartoe te kunnen bijdragen in het bestaan van anderen. Soms is het genoeg om enkel deelgenoot te zijn van de zinervaring van de ander en dat te laten gebeuren, zoals de vriendin van Cuong Lu. Soms verheldert het gesprek de rode draad van zingeving in 
het handelen, als een levensweg, ontdekte Van Dalen. En zin ervaren is in het beste geval een wederkerige ervaring in de relatie, zoals Giebner aangaf.

Er rest nog één vraag uit de elementen van de vraagstelling. In het model van Job Smit werd duidelijk dat bij het verdiepen van wat iemand in een levenscrisis bezighoudt, het teruggrijpen op voorhanden zijnde levensbeschouwelijke overtuigingen en praktijken het actuele perspectief kan helpen vergroten en - in een latere fase - ook bijdragen tot symbolisering. Maar wat indien beide gesprekspartners een verschillende levensbeschouwelijke achtergrond hebben? Welke strategieën worden dan in het gesprek gehanteerd? Verandert het proces dan of komen er nieuwe uitdagingen bij?

\section{Zinervaring en interreligieuze spiritualiteit}

De ervaringen van zin zijn gekoppeld aan het zingevingskader, aldus Mooren. Tot voor kort deden mensen dergelijke ervaringen van zin veelal op binnen hun eigen levensbeschouwelijke zuil. Daar ontmoetten ze anderen die hetzelfde referentiekader deelden. Dat was wel zo gemakkelijk want de talige interpretatie van ervaringen werd vrijwel meteen verstaan. Geestelijk verzorgers opereerden categoriaal, wat nog steeds de aanbevolen praktijk is bij defensie en justitie. Ook in zorg en welzijn wordt het gesprek met iemand van de eigen traditie nog steeds gefaciliteerd, wanneer de cliënt erom vraagt en wanneer dit mogelijk is. De basisassumptie is dat het bevorderen van nieuwe zin door cliënten het beste gebeurt door een ambtsdrager van de traditie waarin ze zich thuis voelen, want deze deelt hetzelfde wereldbeeld, mensbeeld en godsbeeld, levensperspectief, ethiek en leefregels - de aspecten van het zingevingskader volgens Mooren.

Anke Liefbroer (2020) heeft in haar proefschrift laten zien hoe de zingevingscommunicatie eruit ziet wanneer de gesprekspartners een verschillende religieuze achtergrond hebben. In haar empirisch onderzoek worden zowel cliënten als geestelijk verzorgers hieromtrent ondervraagd. Beide groepen zijn verbazingwekkend positief over het interreligieus gesprek. Het verschil in traditie maakt het zingevend gesprek niet onmogelijk, maar wordt juist als een verrijking beleefd.

Zoals al eerder aangegeven zijn er globaal gezien twee strategieën die gehanteerd kunnen worden door de gespreksbegeleider. De eerste noemt Liefbroer de 'neutraliserende strategie'. Daarin worden de verschillen in 
levensbeschouwing tussen beide gesprekspartners niet weggemoffeld, maar er wordt toch minder nadruk op gelegd. Daarentegen worden de overeenkomsten in levensbeschouwing beklemtoond. Welke nieuwe zin er concreet gevonden wordt, is niet meteen duidelijk. Het vinden van een gemeenschappelijke basis blijkt de ontmoeting te bevorderen en ook als zinvol beleefd te worden door beiden. De tweede strategie duidt Liefbroer aan als 'code switching'. De gespreksbegeleider zet de eigen levensbeschouwing - voor zover dat kan even tussen haakjes om zich helemaal te richten op die van de ander. De bedoeling is om de levensbeschouwing van de ander te gebruiken als referentiekader om nieuwe zin in de ontstane levenssituatie te vinden. Of dat lukt zal afhangen van het vermogen van beide gesprekspartners om de actuele beleving te kunnen relateren aan elementen van deze levensbeschouwing op een zodanige wijze dat deze elementen als vitale krachtbron tot zinvinding verschijnen. En zoals we eerder hebben aangegeven komen elementen uit levensbeschouwingen pas in tweede en later in de vierde fase van het begeleidingsgesprek - volgens Job Smit - aan de orde, om het perspectief te verbreden en te verdiepen en om de nieuwe ervaring van zin te symboliseren.

In zijn door Ren Lantman postuum uitgebrachte laatste werk heeft Aad de Jong nog een derde strategie uitgewerkt. In het interreligieus gesprek dient de geestelijk verzorger volgens hem te getuigen van de eigen levensbeschouwing.7 De formele levensbeschouwing krijgt hier een unieke, persoonlijke invulling. In het gesprek met iemand van een andere levensbeschouwing laat de geestelijk verzorger doorklinken persoonlijk geraakt te zijn in de eigen spiritualiteit door het verhaal van de ander. Natuurlijk is de geestelijk verzorger zich er in alle bescheidenheid van bewust enkel voor zichzelf te kunnen spreken, maar toch wordt niet geschroomd dat de ander aan te reiken. ${ }^{8}$

Volledigheidshalve vermeld ik dat de ambitie van De Jong verder reikt. Het getuigen is niet enkel aan de orde in het persoonlijk gesprek met een cliënt. Ook in de dialoog met collega's van andere disciplines en met het beleid van de organisatie zal de geestelijk verzorger in zijn ogen de persoonlijke levensbeschouwelijke inspiratie dienen in te brengen. Hij spreekt dan van 'coöperatie'. In feite is dat ook getuigen, maar dan niet op individueel of groepsniveau met cliënten, maar op het niveau van de organisatie. Vanzelfsprekend is ook hier van belang te kijken welk taalspel aan de orde is. Daarmee wordt de interreligieuze geestelijk verzorging verruimd naar de context buiten het tweegesprek. In eerste instantie gaat het om de eigen context van waaruit beide gesprekspartners elkaar ontmoeten, maar ook om de context waarin ze elkaar ontmoeten - thuis, in één of andere zorg- of welzijnspraktijk of in een 
instelling. Tenslotte is ook de cultureel-maatschappelijke context aan de orde als min of meer bepalend voor de wijze waarop gesprekspartners de dialoog met elkaar aangaan.

Wanneer de gesprekspartner een andere levensbeschouwelijke achtergrond heeft, komt er voor de begeleider dus nog een extra uitdaging bij, namelijk ten aanzien van het inzetten van levensbeschouwelijke elementen. Het gaat om het bewust gebruik van één van de door Liefbroer en De Jong genoemde strategieën in het interlevensbeschouwelijk gesprek: uitgaan van de overeenkomsten tussen beide levensbeschouwingen ('neutraliseren'), zich richten op de levensbeschouwing van de gesprekspartner ('code switching') of zich richten op de eigen levensbeschouwing van de begeleider ('getuigen'). Smeets en De Vries hebben gerapporteerd over hun ervaringen met de eerste twee strategieën in de post-initiële opleiding Klinisch Pastorale Vorming. In het interlevensbeschouwelijk gesprek met cursisten blijken er veel overeenkomsten te bestaan inzake de religieuze en de morele ontwikkeling en dat wordt door de deelnemers als verrijkend ervaren. Tegelijk werd de specifieke eigenheid van de levensbeschouwing van de cursisten in ogenschouw genomen. De uitkomst daarvan was dat de structuur van de religieuze en morele ontwikkeling van cursisten uit verschillende levensbeschouwingen dezelfde is, maar dat de verschillende aspecten ervan en de concrete inhoud per levensbeschouwing verschillen (Smeets 2017; Smeets \& De Vries 2018). In de rol van docent lijkt het gebruik van de derde strategie minder voor de hand te liggen: een docent organiseert immers leerprocessen waarin de persoonlijke reflectie van de cursisten en de dialoog binnen de onderwijsgroep voorop staan.

Tot hiertoe heb ik het doen voorkomen alsof de levensbeschouwing van beide gesprekspartners éénduidig tot een welbepaalde traditie gerekend kan worden. Tegenwoordig komt het echter veel meer voor dat mensen uit meerdere tradities putten. Wat dit betekent voor interlevensbeschouwelijke begeleiding is nog weinig verdisconteerd in de publicaties waarnaar we verwezen hebben. Bovendien is er nog een andere factor die door de geciteerde auteurs onvoldoende is belicht en dat is de rol van de bredere cultuur. Ook deze heeft een invloed op de wijze waarop het zingevingsproces zich ontvouwt en dus ook op het begeleidingsgesprek over zingeving. Mogelijk hebben beide gesprekspartners dezelfde levensbeschouwing, maar komen ze uit een verschillende cultuur. Mogelijk hebben beide gesprekspartners een andere levensbeschouwing, maar delen ze dezelfde cultuur - die de verschillen verrassend overbrugt (Aoulad Baktit \& Smeets 2018). En dan heb ik het alleen nog maar over 
hoe beide gesprekspartners zich op dit punt tot elkaar verhouden. Ook bij elke persoon op zich kan er overeenkomst en verschil bestaan tussen cultuur en levensbeschouwing. Soms ligt de cultuur in de lijn van de levensbeschouwelijke opvattingen, soms bestaat er een spanning tussen beide. Een treffend voorbeeld van dat laatste is recent onderzocht door Greijn, Aoulad Baktit, Koenen en mijzelf in het ziekenhuis waar deze onderzoekers en ik aan verbonden zijn: de tweede, derde en soms al vierde generatie inwoners uit een niet-westerse cultuur. Deze patiënten hebben de levensbeschouwing van hun (groot)ouders, maar nemen grotendeels de seculiere cultuur van hun leeftijdsgenoten over. Om de hybride leefsituatie van jonge patiënten uit een niet-westerse cultuur beter te verdisconteren in de begeleiding hebben wij (de onderzoekers) gebruik gemaakt van het sociologisch model van Hofstede e.a. (Greijn e.a., 2020). Dat piramidemodel plaatst de individuele persoonlijkheid boven op de cultuur, die op zijn beurt rust op de menselijke natuur. De unieke ervaringen van zingeving van een individu kunnen pas begrepen en begeleid worden in het licht van de gewoontes, waarden, taal, gebaren, symbolen en rituelen van de cultuur waarin dat individu leeft en wat mensen in het algemeen met elkaar delen, zoals het ervaren van emoties en de behoefte aan sociaal contact. Net als De Jong benadrukken Hofstede e.a. het belang van taal - en de analyse van de gehanteerde taal in begeleiding - als onderdeel, niet alleen van de levensbeschouwing, maar van de collectieve mentale programmering zoals zij de cultuur noemen. Van daaruit verdient hybriditeit van cultuur en levensbeschouwing veel meer aandacht in de begeleiding.

Mede op basis van deze laatste studie concludeer ik dat interreligieuze geestelijke verzorging niet op zichzelf mag staan, maar dat ze een onderdeel dient te zijn van de bredere interculturele zorg. Op die manier wordt de begeleiding inzake zingeving verbonden met zorg en welzijnszorg voor de andere dimensies van het leven: de lichamelijke gezondheid, het psychisch welzijn en de sociale en materiële levensomstandigheden. Idealiter gebeurt dat in interprofessionele samenwerking, zodat de inzet geïntegreerd wordt. Dan gaat het ook niet enkel om begeleiding en ondersteuning van individuen, maar ook van groepen en bredere gemeenschappen. Een kwarteeuw lang reeds is dat de visie die wordt uitgedragen vanuit de 'Society for Intercultural Pastoral Care and Counseling'. Klacht en aanklacht, bestrijden van onrecht en streven naar vrijheid zijn niet enkel thema's voor interreligieus gesprek en begeleiding, maar ook onderdeel van coöperatieve actie om de levenssituatie van mensen te verbeteren. 
Daarmee is er een antwoord te geven op de laatste deelvraag. Wat betekent het als de gesprekspartner een andere cultuur en levensbeschouwing heeft dan de begeleider? En wat is de rol van de begeleider in het interlevensbeschouwelijk gesprek? Om met het laatste te beginnen: deze kan drie strategieën hanteren. De zingevingsbegeleider kan ofwel zoeken naar overeenkomsten tussen de levensbeschouwingen van de gesprekspartners (neutraliseren), ofwel zich richten op de levensbeschouwing van de ander ('code-switching') ofwel zich richten op de eigen levensbeschouwing en daarvan getuigen. Vervolgens is het zo dat de levensbeschouwing van de gesprekspartner zich op een bepaalde manier verhoudt tot de cultuur waarin deze persoon leeft. Niet altijd convergeren beide elementen, soms is er sprake van hybriditeit. Daarom moet interreligieuze geestelijke verzorging ingebed te zijn in interculturele zorg. Deze reikt per definitie verder dan het interactionele niveau, waardoor de interlevensbeschouwelijke geestelijke verzorging zich ook op organisatieniveau en maatschappelijk niveau dient te oriënteren.

\section{Conclusies en aanbevelingen voor interlevensbeschouwelijke geestelijke verzorging}

Uitgangspunt van deze bijdrage was de volgende vraag: Hoe kan ik als begeleider de ander helpen om hier en $\mathrm{nu}$ - in dit gesprek - zin te ervaren? In discussie met de literatuur kan ik de vier elementen van deze vraag nu als volgt beantwoorden.

Het eerste element betrof de ervaring van zin. Het zingevingsproces omvat een dynamische wisselwerking tussen actief zin geven en receptief zin ontvangen. Het proces omvat alle aspecten van het menselijk functioneren. Voor het ervaren van zin is het lichamelijk en affectief functioneren naast het cognitieve erg belangrijk; het vermogen tot verbeelding wordt geactiveerd. Ik heb negen elementen in het ervaren van zin onderscheiden, zodat bij de analyse van een concrete zinervaring nagegaan kan worden welke elementen op de voorgrond treden en welke minder. Vooral de existentiële benadering in filosofie, theologie en sociale wetenschappen heeft geholpen om meer zicht te krijgen op de permanente uitdaging inzake het ervaren van zin. Het bestaan in tijd en ruimte plaatst ons voor levensvragen inzake eindigheid, vrijheid, eenzaamheid en ultieme zin of zinloosheid. De lichamelijke gewaarwording - vanuit zintuiglijke indrukken - blijkt een goed startpunt te zijn voor de ervaring van zin, waarbij vooral ook onze verbeelding wordt aangesproken. Een 
crisissituatie brengt de mens tot aan de grenzen van de bestaande zingeving. Dan bij uitstek komt het aan op de receptieve openheid voor gewaarwordingen en andere zaken die zich aan de mens voordoen.

Het tweede element van de vraagstelling betrof het gesprek, dat gericht is op het stimuleren van een nieuwe zinervaring. Er werd aangesloten bij het vijf fasen model van Job Smit. Enerzijds wordt in dat model het intrapsychische proces van zinervaring bij de cliënt gevolgd. Anderzijds wordt daaraan op gestructureerde wijze de taak van de begeleider verbonden om dit proces te stimuleren. Ook wordt verhelderd op welke momenten in de begeleiding inhouden uit levensbeschouwelijke tradities een rol kunnen spelen.

Het derde en vierde element van de vraagstelling betrof de gesprekspartners. Wanneer beide gesprekspartners een andere levensbeschouwelijke achtergrond hebben, kan het inzetten van inhouden uit deze tradities volgens drie strategieën verlopen. De begeleider kan zich richten op overeenkomsten tussen deze tradities ('neutraliseren'), op de traditie van de ander ('code-switching') of op de eigen traditie ('getuigen'). Er is in dit stadium van onderzoek nog niets te zeggen over welke strategie in welke situatie de voorkeur heeft, waarbij een belangrijk criterium in elk geval dient te zijn: wat draagt bij tot een nieuwe ervaring van zin.

Bij het verdiepen van wat iemand in een levenscrisis bezighoudt, kan het teruggrijpen op voorhanden zijnde levensbeschouwelijke overtuigingen en praktijken het actuele perspectief verdiepen en verbreden en nadien ook bijdragen tot symbolisering - dat is de mogelijke rol van deze levensbeschouwelijke inhouden in dit proces. Hoe het ervaren van nieuwe zin - in de fase die Job Smit het 'laten' noemt - plaatsvindt, komt in de literatuur over interlevensbeschouwelijke geestelijke verzorging onvoldoende uit de verf. Daardoor krijgen de levensbeschouwelijke inhouden - de kennis en het gebruik ervan een te grote rol toebedeeld. Eveneens onderbelicht tot nu toe blijft de inbedding van levensbeschouwingen in de cultuur en de dynamiek die dat met zich meebrengt voor de gesprekspartners op zich en in hun ontmoeting met elkaar. Interculturele geestelijke verzorging kan het juiste kader bieden waarbinnen de interlevensbeschouwelijke geestelijke verzorging verder gestalte kan krijgen. Het verbindt de aandacht voor de zingevingsdimensie met de andere dimensies van het bestaan. De geestelijk verzorger wordt uitgedaagd tot coöperatie met andere professionals die zich bezighouden met het lichamelijk, psychisch en sociaal welzijn van individuen, groepen en gemeenschappen. 
Vanuit de beantwoording van de vraagstelling wil ik vijf aanbevelingen formuleren voor de praktijk van het gesprek over zingeving tussen gesprekspartners met een diverse levensbeschouwelijke achtergrond, één aanbeveling voor opleiding en nascholing en drie aanbevelingen voor vervolgonderzoek.

Om te beginnen de aanbevelingen voor de procesgang van de interlevensbeschouwelijke begeleiding in vijf fasen.

1. Het naderen tot elkaar is een eerste fase die bewust aandacht verdient. De professional verdiept zich eerst en vooral in de culturele achtergrond van de gesprekspartner. Vervolgens stelt hij/zij zich de vraag: hoe ver reikt mijn kennis van de levensbeschouwing van degene die ik ga ontmoeten? Het antwoord op deze vraag zal verderop in de begeleiding meebepalend zijn of de professional capabel is tot een 'code switching'-strategie - wanneer die gewenst is - of dat de professional eventueel zal doorverwijzen naar een collega die dezelfde levensbeschouwing van de gesprekspartner deelt. Naderen is niet louter een verbale aangelegenheid, het is een tot elkaar komen met de totale persoon die de gesprekspartners zijn (dus ook lichamelijk, psychologisch en sociaal).

2. Verdiepen wat de ander hier-en-nu bezighoudt, in de tweede fase, betreft de hele existentie met een exploratie van de levensthema's en -vragen zoals die zich bij deze gesprekspartner uniek voordoen. In deze exploratie speelt verbeelding een belangrijke rol. Levensbeschouwelijke overtuigingen en praktijken kunnen vervolgens een rol spelen als perspectief op deze beleving, maar komen dus pas in tweede instantie aan de orde. En dan pas kan een strategie gekozen worden die daarbij past: neutraliseren, 'code switching' of getuigen.

3. In de derde fase komt het doel van de begeleiding het meest duidelijk op de voorgrond: het ervaren van nieuwe zin in de situatie waarin de gesprekspartner verkeert. De begeleider is terugtredend present bij de openheid van de gesprekspartner voor het ervaren van (nieuwe) zin. De gewaarwording op basis van zintuiglijke indrukken speelt hierbij een belangrijke rol.

4. In de vierde fase kan de begeleider woorden helpen geven aan de zinervaring. Hier kunnen levensbeschouwelijke inhouden opnieuw een rol spelen bij het symboliseren, al wordt hier opnieuw vooral veel verbeeldingskracht van de begeleider gevraagd, zeker ook om zich voor te stellen hoe deze zinervaring in het leven van 'straks' geïntegreerd kan worden.

5. Zo komt het gesprek tot een afronding, dat is de vijfde en laatste fase. Er wordt gezocht naar taal en vorm om de nieuw ervaren zin voor het leven te bevestigen of te bekrachtigen. Hierbij is de verbeelding van beide gespreks- 
partners weer belangrijk en kan de begeleider de eigen rituele competentie inzetten. Een evaluatieve terugblik mag niet vergeten worden.

Vervolgens formuleer ik een aanbeveling voor opleiding en nascholing van geestelijk verzorgers en andere zingevingsprofessionals, aansluitend bij de inzichten die met name naar voren kwamen ten aanzien van de rol van de begeleider bij het stimuleren van het ervaren van zin in het interlevensbeschouwelijk gesprek.

6. Geestelijk verzorgers en andere zingevingsprofessionals zullen zinervaring moeten kunnen zien en helpen ontwikkelen, bij zichzelf en anderen. In de opleiding moet minder nadruk komen op de inhoud van levensbeschouwingen en meer op het proces van zin-faciliterende presentie en interventie. Daarbij is de analyse van de taal die in de zin-begeleiding wordt gehanteerd een belangrijk instrument, als onderdeel van een bredere cultuur-sensitiviteit. Het is dus niet voldoende dat de geestelijk verzorger een basale kennis heeft van alle mogelijke tradities en mensen van daaruit probeert te begrijpen. Geestelijk verzorgers moeten hun persoonlijke zingeving niet buitenspel plaatsen, maar ook verder ontwikkelen. Het ambt of daaraan vergelijkbaar mandaat kan daartoe een stimulans zijn. Maar of de begeleider een ambtelijk vertegenwoordiger van een bepaalde traditie is, staat niet voorop. De eerste vereiste is een inzicht hebben in hoe zingeving in het leven van een ander speelt en hoe deze gestimuleerd kan worden, als onderdeel van geïntegreerde aandacht voor alle aspecten van het menselijk bestaan. In theologische, c.q. religiewetenschappelijke termen betekent dit: zij leren - met de woorden van De Jong - getuigen van de geest die gericht is op het heil, dat gezondheid en welzijn includeert en verder reikt naar de bestemming van het menselijk bestaan. In godsdienstpsychologische termen betekent dit: zij kunnen onderscheiden wanneer die bestemming wordt ervaren en er voor mensen - met de woorden van Alma en Smaling - doelgerichtheid is, samenhang, waarde-volheid, verbondenheid, transcendentie, competentie en erkenning, motivatie en welbevinden in één. In mystieke termen betekent dit: zij zijn zich ervan bewust dat in en naast de dagelijkse ervaring van broosheid er voor sommige cliënten - zeker voor hen die zich door bepaalde leefregels daarop toeleggen - ook een ervaring van eenheid met de werkelijkheid mogelijk is. Door de erkenning van de menselijke autonomie sinds de Verlichting is er gelukkig meer ruimte gekomen voor de exploratie van de subjectieve beleving, die ontsnapt aan de controle door het leergezag van de instituties 
Tenslotte formuleer ik drie aanbevelingen voor vervolgonderzoek, in aansluiting op de bevindingen inzake het proces van de gewaarwording van nieuwe zin, het eindpunt van het begeleidingsgesprek en de verhouding tussen religie en cultuur in de persoon van de gesprekspartner.

7. In toekomstig onderzoek rond interlevensbeschouwelijke geestelijke verzorging wil ik de volgende onderwerpen onder de aandacht brengen. Om te beginnen denk ik aan de wijze waarop in het interlevensbeschouwelijk gesprek nieuwe zin ervaren wordt langs de weg van de lichamelijke gewaarwording, de bewustwording van wat zich via zintuiglijke indrukken aandient - kortom de mogelijke rol van 'focusing'. Vervolgens denk $\mathrm{ik}$ aan de esthetische waarneming die verbonden is met het vermogen tot verbeelding - vooral dan het gebruik van kunst. Tenslotte denk ik aan de analyse van de talige interventies van de gespreksbegeleider - waarbij het door De Jong aangedragen voorstel verbonden kan worden met de basismethodiek van Smit.

8. In het onderzoek naar het effect van de inzet van geestelijke verzorging verdienen kwalitatieve gegevens over de ervaring van zin een prominente plaats. Er kan aangesloten worden bij wat in de evaluatieve terugblik in de vijfde fase van Job Smit, die van de afronding van het gesprek, aan de orde komt. Wat dan gedeeld wordt, kan eventueel, uiteraard met toestemming van de gesprekspartner, ingezet worden bij een zogenaamde 'Patient Reported Experience Measurement'.

9. Interlevensbeschouwelijke zorg zou inzake onderzoek meer verbonden moeten worden met interculturele zorg. Daarmee wordt het object verbreed en wordt het onderzoeksteam ook interdisciplinair. Samenwerking met collega's (uit de antropologie en godsdienstsociologie naast geneeskunde, verplegings- en gezondheidswetenschap, psychologie, pedagogiek en maatschappelijk werk) zal leiden tot een dieper inzicht in onderzoeksuitkomsten. 


\section{Noten}

1 Hoe deze discussie speelt voor de grote groep moslim jongeren, moet de toekomst uitwijzen. Zij worden enerzijds beïnvloed door de geloofsopvattingen van hun (groot) ouders, anderzijds participeren zij voluit in de cultuur van hun leeftijdsgenoten (Greijn e.a. 2020).

2 Daarvoor verwijs ik naar de bijdrage van anderen (zie bijvoorbeeld Van de Geer, 2017; Hölsgens, 2020; Van der Leer, 2020; Van Meurs e.a., 2017 ; Willemse e.a., 2020).

3 Daarbij baseert hij zich op een aantal auteurs, o.a. Wuchterl.

4 Het motto 'du musst dein Leben ändern' van Sloterdijk wordt dan niet enkel van toepassing op de crisis in het leven van de cliënt.

5 Daarmee gaan we niet in op de eveneens relevante bijdragen van auteurs die enigszins buiten deze dialoog zijn gebleven, zoals de bijdrage van psycholoog Stevens ('In gesprek met een ander. Het pastorale gesprek opnieuw ter sprake' -1990) en die van humanisten - in het spoor van Alma, Smaling en Mooren - zoals Jorna ('Echte woorden. Authenticiteit in de geestelijke begeleiding'- 2008) en Duyndam e.a. ('Wegwijs in levensvragen. Over humanistisch geestelijke verzorging'-2019).

6 Met name gaat het om een combinatie van de modellen van Rogers, Lang \& Van der Molen, Egan en Stiles.

7 Zoals al eerder opgemerkt lijkt zijn getuigenis-concept op Ricoeurs 'attestatie'.

8 De Jong maakt gebruikt van de taaldadentheorie van Searle als instrument om de geestelijk verzorger bewust te maken van welk soort taal op welk moment in het gesprek aan de orde is.

\section{Literatuur}

Alma, H. (2020),

Het verlangen naar zin. De zoektocht naar resonantie in de wereld, Utrecht: Ten Have.

Alma, H. \& A. Smaling (2009),

Waarvoor je leeft. Studies naar humanistische bronnen van zin, Amsterdam: Humanistic University Press.

Aoulad Baktit, S. \& W. Smeets (2018),

“U bent als een zuster voor mij”. Interlevensbeschouwelijke counseling, in: Psyche \& Geloof, 29 (2), 119-125.

Ceuninck van Capelle, A. de (2017),

Lived Experiences of People with Recently Diagnosed Multiple Sclerosis. An Analysis Drawing on Phenomenology and Ethics of Care, Utrecht: Universiteit voor Humanistiek.

Dalen, E. van (2019),

De interpretatiecrisis bij ongeneeslijke kanker. Een religiewetenschappelijk onderzoek naar verklaringen, het onverwachte, tragiek en de gewaarwording van het andere, Münster: LIT.

Dijkstra, J. (2007),

Gespreksvoering bij geestelijke verzorging. Een methodische ondersteuning om betekenisvolle gesprekken te voeren, Amsterdam: Boom. 
Dijkstra, J. (2012),

De absolute werkelijkheid in het licht van eeuwenoude religieuze tradities, Geesteren: $\mathrm{A}_{3}$ boeken.

Evers, H. \& J. de Groot (2017),

Contemplative Listening. A Rhetorical-Critical Approach to Facilitate Internal Dialogue, in: Journal of Pastoral Care \& Counseling, 71 (2), 114-121.

Frankl, V. (1979),

Unheard Cry for Meaning. Psychotherapy and Humanism, New York: Simon \& Schuster.

Geer, J. van de (2017),

Learning Spiritual Care in Dutch Hospitals, Groningen: Rijksuniversiteit.

Gendlin, E. T. (1998),

Focusing-oriented psychotherapy. A Manual of the Experiential Method, New York: Guilford.

Giebner, B. (2015),

Gedeelde ruimte. De ontvankelijkheid van zorgverleners in patiëntencontacten, Delft: Eburon.

Greijn, C.M., E. Koenen, S. Aoulad Baktit \& W. Smeets (2020),

Thuis in meerdere culturen. Hybriditeit bij jonge patiënten met een Turkse of Marokkaanse achtergrond in de palliatieve fase, in: Tijdschrift Geestelijke Verzorging, 23 (99), 22-30.

Hölsgens, V. (2020),

Gebroken verhalen aan de keukentafel, over zingeving in de Nederlandse verzorgingsstaat, Utrecht: Universiteit voor Humanistiek.

Leer, N. van der (2020),

Zinvolle zorg in het verpleeghuis. Een onderzoek naar de samenhang tussen zorg en zin en de rol van de geestelijk verzorger, Utrecht: Kok.

Leijssen, M. (2001),

Gids voor gesprekstherapie, Zaandam: De Tijdstroom.

Leijssen, M. (2006),

Validation of the body in psychotherapy, in: Journal of Humanistic Psychology, 46 (2), $126-146$.

Leijssen, M. (2007),

Tijd voor de ziel. Spiritualiteit en zingeving vanuit psychotherapie, Tielt: Lannoo.

Liefbroer, A. (2020),

Interfaith Spiritual Care, (dissertation), Amsterdam: UVA.

Meurs, J. van, W. Smeets, K. C. P. Vissers, M. Groot \& Y. Engels (2017),

Nurses Exploring the Spirituality of Their Patients With Cancer. Participant Observation on a Medical Oncology Ward, in: Cancer Nursing, DOI:10.1097/ NCC.0000000000000526. 
Mooren, J.H.M. (2011),

Verbeelding en bestaansoriëntatie, Utrecht: De Graaff.

Moustakas, C. (1979),

Eenzaamheid, Rotterdam: Lemniscaat.

Park, C.L. \& I.A. Gutierrez (2013),

Global and situational meanings in the context of trauma. Relations with psychological well-being, in: Journal Counselling Psychology Quarterly, 26 (1), 8-25.

Smeets, W. (2015),

Supervisie en spirituele ontwikkeling, in: Psyche a Geloof, 26 (4), 247-261.

Smeets, W. (2017),

Ethiek en supervisie. Cliëntgerichte en professioneel-biografische invalshoeken, in: Tijdschrift voor begeleidingskunde, 6 (3), 2-11.

Smeets, W. (2019),

Een pastorale of spirituele focus in supervisie, in: Handelingen. Tijdschrift voor Praktische Theologie en Religiewetenschap, 46, 2.

Smeets, W. \& A. de Vries (2018),

Religieuze ontwikkeling in de Klinische Pastorale Vorming, in: Handelingen, Tijdschrift voor Praktische Theologie en Religiewetenschap, 45 (4), 41-47.

Smit, J. (2006),

Tot de kern komen. De kunst van het pastorale gesprek, Kampen: Kok.

Smit, J. (2011),

Competenties voor de pastorale communicatie met mensen met een verstandelijke beperking. Een praktisch-theologisch onderzoek naar leerprocessen van pastores, Amsterdam: Vrije Universiteit.

Smit, J. (2015),

Antwoord geven op het leven zelf. Een onderzoek naar de basismethodiek van geestelijke verzorging, Utrecht: Eburon.

Smit, J. \& W. Smeets (2018),

De basismethodiek van geestelijke verzorging op handelingsniveau, in: Psyche Q Geloof, 29 (2), 86-95.

Volkskrant (2020),

Interviews door Fokke Obbema, editie 24.05.2020 en 05.07.2020.

Willemse, S., W. Smeets, E. van Leeuwen, T. Nielen-Rosier, L. Janssen \& N. Foudraine (2020),

Spiritual care in the intensive care unit. An integrative literature research, in: Journal

of Critical Care, 57, 55-78.

Yalom, I. (2012),

Tegen de zon inkijken. Doodsangst en hoe die te overwinnen, Amsterdam: Balans. 
